\title{
Rola i potencjał terapeutyczny sfingolipidowego szlaku sygnalizacyjnego w nowotworach hematologicznych
}

\section{Role and therapeutic potential of sphingolipids signaling in hematological malignances}

\author{
Marzena Wątek ${ }^{1,2}$, Bonita Durnaś ${ }^{2}$, Tomasz Wollny², \\ Małgorzata Żendzian-Piotrowska ${ }^{3}$, Marcin Pasiarski², Stanisław Góźdź ${ }^{2}$ \\ ${ }^{1}$ Klinika Hematologii, Instytut Hematologii i Transfuzjologii, Warszawa \\ ${ }^{2}$ Klinika Hematologii i Transplantacji Szpiku, Ośrodek Leczenia Ostrych Białaczek, \\ Świętokrzyskie Centrum Onkologii, Kielce \\ ${ }^{3}$ Zakład Fizjologii, Uniwersytet Medyczny w Białymstoku
}

\section{Streszczenie}

Brak skutecznych metod pozwalajacych na osiagnięcie równowagi między niekontrolowana proliferacja $i$ apoptoza komórek $w$ procesie nowotworowym stanowi jedna z kluczowych barier postepu $w$ leczeniu. Obecnie wiadomo, ze istotnymi czqsteczkami regulujacymi procesy wzrostu, róznicowania, życia oraz śmierci komórek sq sfingolipidy. Zależie od natury chemicznej sfingolipidy moga pobudzać (S1P, sfingozyno-1-fosforan) lub hamować (ceramid) proliferacje. W wielu różnych badaniach wykazano, że generacja ceramidu $w$ odpowiedzi na terapie cytotoksyczna jest waznym elementem prowadzacym do śmierci komórki. Komórki nowotworowe stosuja różne sposoby ograniczajace wytwarzanie ceramidu i prowadzace do jego usuwania. Dziatanie onkogenne S1P wynika z jego dziatania stymulujacego synteze DNA i ruchliwość chemotaktyczna komórek śródbtonka naczyniowego, jak również stymulacji rozwoju naczyń krwionośnych. Dlatego zastosowanie przeciwciat monoklonalnych anty-S1P jest potencjalnie wartościowa opcja terapeutyczna w hamowaniu rozwoju naczyń krwionośnych warunkujacych wzrost guzów nowotworowych. Dodatkowo udowodniono, ze S1P poza bezpośrednim oraz pośrednim — przez stymulacje uwalniania czynnika wzrostu śródbtonka naczyniowego i podstawowy czynnik wzrostu fibroblastów - dziataniem angiogennym, wplywa na wzrost i potencjat przerzutowy nowotworów. Spośród sfingolipidów ceramid wskazano jako pierwszy indukujacy różnicowanie i śmierć w komórkach ludzkiej biataczki promielocytowej HL-60. Postęp w zrozumieniu roli sfingolipidów, uważanych do niedawna za jedynie sktadowa strukturalna bton komórkowych, umożliwia wykorzystanie w terapii ztożonych wtaściwości tej grupy czasteczek sygnalizacyjnych. Istotne więc stato sie wyjaśnienie roli sfingolipidów $w$ regulacji równowagi między sygnałami proliferacji/przeżywalności komórek $i$ ich śmierci $w$ celu opracowania nowych terapii.

Słowa kluczowe: sfingolipidy, ceramid, sfingozyno-1-fosforan/S1P, fingolimod, białaczka, chłoniak, nowotwory hematologiczne

Hematologia 2018; 9, 4: 318-329

Adres do korespondencji: Marzena Wątek, Klinika Hematologii i Transplantacji Szpiku, Ośrodek Leczenia Ostrych Białaczek, Świętokrzyskie Centrum Onkologii, ul. Artwińskiego 3, 25-34 Kielce, tel. 413674 870, faks 413674871 , e-mail: marzena.watek@wp.pl 


\begin{abstract}
One of the key obstacles in the progress of cancer treatment is the lack of balance between the uncontrolled proliferation and cell apoptosis. It is now known that sphingolipids are essential molecules regulating the processes of growth, differentiation and death of living cells. Depending on their chemical nature, sphingolipids may have a stimulatory (S1P, sphingosine-1-phosphate) or inhibitory (ceramide) effect on cellular proliferation. A number of different studies have shown that the generation of ceramide in response to cytotoxic therapy is an important element leading to cell death. Cancer cells use different methods limiting the production of ceramides that leads to their removal. The effect of oncogenic S1P results from its stimulating effect on DNA synthesis and chemotactic mobility of the vascular endothelial cells and angiogenesis. The use of monoclonal anti-S1P antibodies is potentially a valuable therapeutic option for inhibiting angiogenesis determining the growth of tumors. It was additionally demonstrated that S1P beyond the direct and indirect by stimulating the release of vascular endothelial growth factor and basic fibroblast growth factor angiogenic action has an effect on tumor growth and its metastatic potential. Among the sphingolipids, ceramide was identified first as inducing differentiation and the death of human HL-60 promyelocytic leukemia cells. Progress in understanding the role of sphingolipids was regarded until recently as the only structural component of cell membranes allowing the use in the treatment of complex properties of this group of signaling molecules. Thus, it has become important to clarify the role of sphingolipids in the regulation of the balance between proliferation signals/ /survival rate and death of cells in order to develop new therapies for neoplastic diseases of myeloid and lymphoid origin.
\end{abstract}

Key words: sphingolipids, ceramide, shpingosino-1-phoshate/S1P, fingolimod, leukemia, lymphoma, hematological malignances

Hematologia 2018; 9, 4: 318-329

\section{Wprowadzenie}

Nowotwory układu krwiotwórczego powstają w wyniku zmian klonalnych komórek krwiotwórczych na różnych etapach dojrzewania, poczynając od pluripotencjalnej komórki macierzystej, aż do dojrzałych komórek efektorowych. Zaburzenia te mogą się rozwinąć w komórkach szpiku kostnego, ale również w komórkach wtórnych narządów krwiotwórczych, śledziony, grasicy i węzłów chłonnych. Nowotwory układu krwiotwórczego są ekstremalnie zróżnicowaną grupą chorób od indolentnych proliferacji klonalnych komórek limfo- i mieloidalnych po wysoce agresywne ostre białaczki. Zgodnie $z$ różnorodnością naturalnej historii tych chorób leczenie może obejmować zwykłą obserwację, łagodzenie pojawiających się powikłań, intensywne cykle wielolekowej chemioterapii czy leczenie paliatywne. $\mathrm{W}$ wielu przypadkach perspektywę wyleczenia realizuje się przez autolub allogeniczne przeszczepienie krwiotwórczych komórek macierzystych (allo-HSCT, allogeneic hematopoietic stem cell transplantation). Tradycyjne leczenie cytostatyczne jest często bardzo skuteczne w zmniejszaniu masy nowotworu, brakuje mu jednak specyficzności, co skutkuje znaczną toksycznością w stosunku do zdrowych tkanek. Brak specyficzności doprowadził w konsekwencji do rozwoju terapii celowanych hamujących procesy specyficzne dla procesu nowotworowego, przez co ograniczają jego wzrost i indukują śmierć komórki, natomiast objawy toksyczne zależne od leczenia są minimalizowane. Nadal jednak trwają liczne poszukiwania nowych metod leczniczych.

Sfingolipidowe mediatory sygnałowe reprezentują grupę zewnątrz- i wewnątrzkomórkowych cząstek o plejotropowym działaniu wpływających na ważne procesy komórkowe, włączając nowotworzenie [1]. Sfingomielinowy szlak informacyjny poznano jako trzecią $z$ dróg przezbłonowej transmisji sygnałów. Został opisany po raz pierwszy w 1987 roku przez Kolesnick i Paley [2-4]. Historycznie pierwszym opisanym szlakiem sygnałowym był układ nukleotydów cyklicznych. W układzie tym bodźce docierające do komórki odbiera receptor błonowy związany $z$ białkiem G. Drugi z opisanych szlaków sygnałowych to szlak fosfatydyloinozytolowy transmisji sygnału, który również jest związany $z$ aktywacją białka $G$. W efekcie połączenia liganda $z$ receptorem dochodzi do aktywacji białka G, 


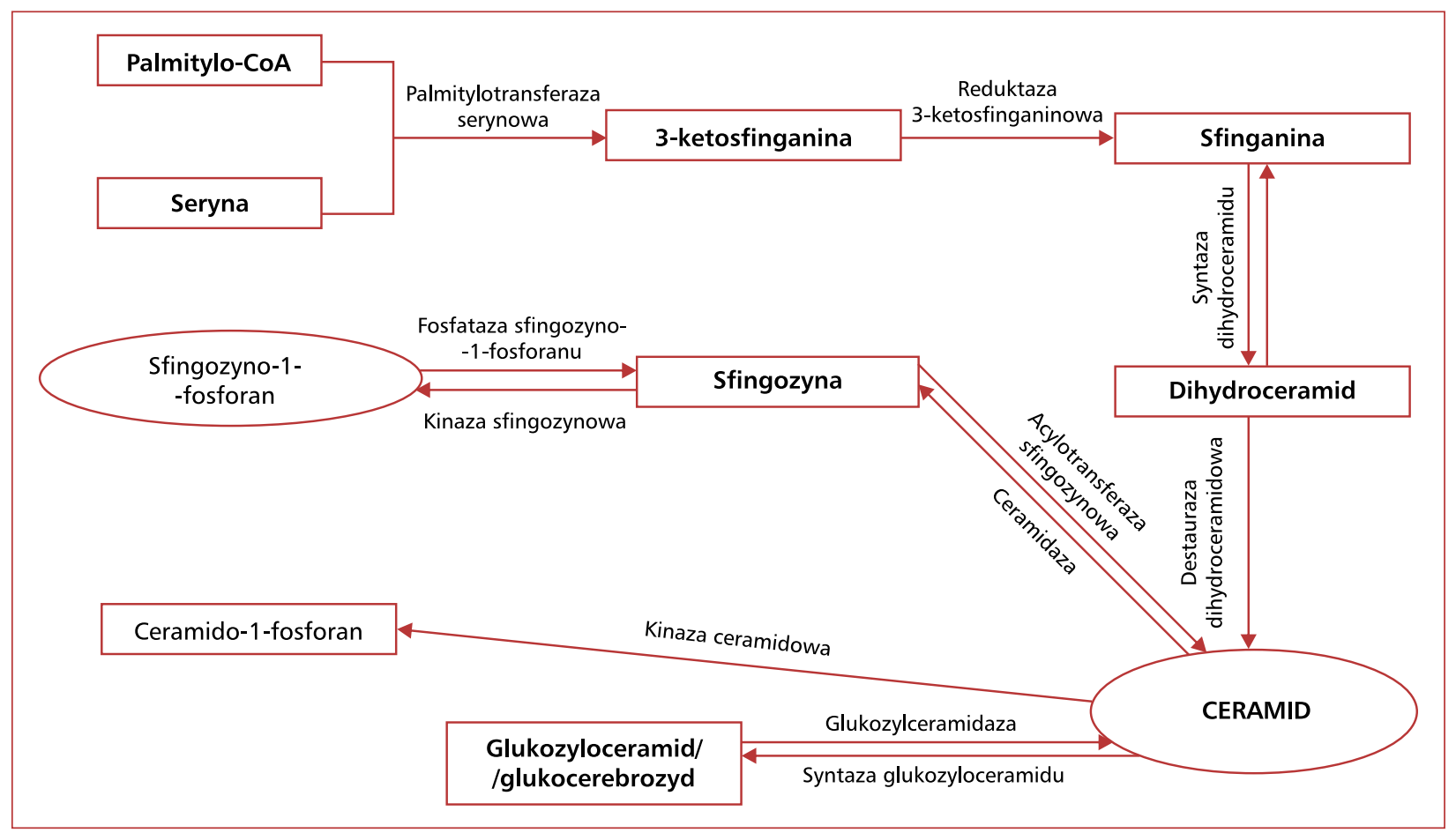

Rycina 1. Schemat metabolizmu sfingolipidów; CoA - koenzym A

Figure 1. Scheme of sphingolipid metabolism; CoA - coenzym A

a w następstwie — do aktywacji fosfolipazy C (PLC, phospholipase C) [2-4].

Sfingolipidy, przez 20 lat uznawane jedynie za budulec błon komórkowych, są dziś cząsteczkami o poznanym wpływie na procesy wzrostu, różnicowania, migracji, życia i śmierci komórek [5]. W zależności od natury chemicznej mogą wpływać pobudzająco na proliferacje komórek (sfingozyno-1-fosforan [S1P, sphingosine-1-phosphate]) lub ją hamować (ceramid) [5]. Ceramid ma silny wpływ hamujący na rozwój „guza” nowotworowego, indukując apoptozę i hamując cykl komórkowy. Działa jako mediator wewnątrz- i zewnątrzkomórkowego szlaku apoptozy [6]. Sfingozyno-1-fosforan wpływa pobudzająco na rozwój większości nowotworów poprzez pobudzanie proliferacji komórek, rozwoju naczyń krwionośnych i hamowanie apoptozy [5]. Jest wysoce prawdopodobne, że dokładne poznanie mechanizmu wzrostu i apoptozy komórek w kontekście działania sfingolipidów umożliwi rozwój nowych metod leczenia opartych na punktach uchwytu w przestrzeni sfingolipidowych szlaków transmisji sygnału. $Z$ tego powodu szlaki te stały się obecnie punktem intensywnych badań służących poszukiwaniu metod terapii celowanych [6].

$\mathrm{W}$ niniejszym opracowaniu skupiono się na omówieniu postępu w badaniach na temat roli sfingolipidów i ich enzymów metabolicznych w proliferacji, przeżyciu i śmierci komórek. Przedstawiono również dostępne dane na temat wpływu sfingolipidów na komórki nowotworów hematologicznych i nowych metod terapeutycznych uwzględniających działanie sfingolipidów na rozwój choroby nowotworowej.

\section{Sfingolipidy i sfingolipidowy szlak przekazywania informacji}

Związki sfingolipidowego szlaku transmisji sygnałów regulują procesy wzrostu i podzialu komórek, a zwłaszcza proces apoptozy. Ich biodostępność w osoczu krwi jest buforowana przez białka osocza [2, 3]. Zawarty w błonie powierzchniowej komórki diacyloglicerol (DAG, diacylglycerol) poprzez aktywację enzymu kwaśnej sfingomielinazy stymuluje hydrolizę sfingomieliny. Podobnie jak wszystkie pozostałe elementy szlaku (ryc. 1) enzym ten jest zlokalizowany w błonie komórkowej [2, 3]. W wyniku hydrolizy sfingomieliny powstaje ceramid (acylosfingozyna), główny wtórny przekaźnik szlaku. W wyniku degradacji ceramidu poprzez enzym ceramidaze (deacylaza acylosfingozynowa) w komórce są uwalniane kolejne cząstki sygnałowe omawianego 
szlaku — sfingozyna (SFO), sfingozylofosfocholina i S1P. Związki te o różnych właściwościach biologicznych warunkują odmienny, często przeciwstawny wpływ na określone procesy biologiczne. Sfingomielinowy szlak przekazywania sygnałów jest stymulowany przez różne czynniki, takie jak: czynnik martwicy nowotworów alfa (TNF $\alpha$, tumor necrosis factor $\alpha$ ), glikokortykosteroidy, interferon, DAG, interleukiny (IL-1, interleukina 1), witaminę D3 (kalcytriol), promieniowanie jonizujące, promieniowanie ultrafioletowe (UV, ultraviolet), wysoką temperaturę, szok tlenowy, szok osmotyczny, niedokrwienie tkanki, wstrząs hipowolemiczny, chemioterapeutyki (np. etopozyd, daunorubicyna) [3, 7-10].

Sfingomielinowy szlak transmisji sygnałów opisano w tkance nerwowej, wątrobie, płucach, mięśniach szkieletowych, mięśniu sercowym, tkance limfoidalnej, śledzionie oraz w błonie śluzowej przewodu pokarmowego. Aktywacja tego szlaku zachodzi przy udziale sfingomielinaz, enzymów, które hydrolizują sfingomielinę $z$ uwolnieniem ceramidu i reszty fosfatydylocholiny. Enzymy te są specyficznymi formami fosfolipaz C $[11,12]$. Efekt ich działania w komórce ujawnia się od kilkunastu sekund do kilkunastu minut po zadziałaniu czynnika indukującego.

Obecnie wiadomo, że głównym źródłem ceramidu w komórce jest jego synteza de novo, a nie jak sądzono jeszcze kilkanaście lat temu — regulacja stężenia poprzez działanie sfingomielinaz [13]. Sfingomielinazy są aktywowane zarówno przez czynniki proapoptotyczne, jak i promitotyczne, indukujące różnicowanie komórek [14]. Aktywacja receptora 1 dla TNF $\alpha$ (TNF-R1, tumor necrosis factor receptor 1 ) skutkuje aktywacją kwaśnej sfingomielinazy i błonowej sfingomielinazy obojętnej, czego efektem jest apoptoza komórki na skutek zwiększonego stężenia ceramidu [15].

Obserwacje kliniczne przez prawie pół wieku wykazały, że w chorobie Gauchera (GD, Gaucher disease) typu 1 częściej występują choroby nowotworowe, szczególnie szpiczak plazmocytowy (PCM, plasma cell myeloma) i chłoniaki B-komórkowe. Choroba Gauchera to lizosomalna choroba spichrzeniowa. Wydaje się, że zaburzenia metabolizmu sfingolipidów w tej chorobie mogą stanowić model patogenezy nowotworów [16]. Choroba jest spowodowana wrodzonym niedoborem kwaśnej $\beta$-glukozydazy związanym z mutacją w genie $G B A 1$, kodującym białko enzymu, glukocerebrozydazę. Prowadzi to do gromadzenia glukozyloceramidu w lizosomach jednojądrowych fagocytów i rozregulowaniu układu odpornościowego. Całkowite ryzy- ko powstania nowotworu jest znacząco zwiększone, w tym zwłaszcza nowotworów układów chłonnego krwiotwórczego. Ryzyko zachorowania na PCM szacuje się na prawie 37-krotnie wyższe niż w populacji ogólnej [16]. Wykazano, że niedobór GBA1 u myszy powoduje wzrost wartości glukozyloceramidu i glukozylosfingozyny w osoczu, co indukuje powstawanie chłoniaków z limfocytów B (11 z 21 myszy) oraz gammapatie monoklonalne ( 11 z 39 myszy). Przyczyna tych nowotworów nie została wyjaśniona, jednak zwracają uwagę nieprawidłowe gromadzenie oraz niedobór sfingolipidów, takich jak ceramid i sfingozyna [16].

\section{Sfingozyno-1-fosforan — bioaktywny lipid o działaniu proonkogennym}

Bioaktywny metabolit sfingolipidów S1P uznaje się obecnie za regulator wielu procesów fizjologicznych i patofizjologicznych, w tym powstawania nowotworów, miażdżycy tętnic, cukrzycy i osteoporozy. Sfingozyno-1-fosforan jest wytwarzany w komórkach przez dwa izoenzymy kinazy sfingozyny - SphK1 i SphK2 [8]. Izoenzym SphK1 promuje wzrost i przeżycie komórek, podobnie SphK2 w prawidłowych stężeniach, natomiast nadekspresja SphK2 powoduje przeciwstawne efekty. W rzeczy samej S1P i SphK1 od dawna są wiązane z opornością zarówno pierwotnych komórek białaczkowych, jak i linii komórkowych białaczki na apoptozę indukowaną poprzez powszechne stosowane środki cytotoksyczne [17]. Wcześniejsze badania sugerowały rolę balansu ceramid/S1P we wrażliwości komórek na apoptozę. W badaniu nad komórkami Jurkat T, w którym przesunięto balans ceramid/S1P na korzyść ceramidu, znacząco wzrósł efekt cytotoksyczny promieniowania jonizującego [18]. Co więcej, F-12509a - inhibitor kinazy sfingozyny - prowadzi do akumulacji ceramidu, zmniejszenia zawartości S1P, co powoduje apoptozę komórek ostrej białaczki szpikowej (AML, acute myeloid leukemia) HL-60 w równej mierze chemioopornych, jak i chemiowrażliwych. Dodanie S1P lub nadekspresja SphK1 hamują ten efekt [19]. Izoenzym SPHK1 ulega nadmiernej ekspresji i konstytutywnej aktywacji w komórkach blastycznych AML ale nie w prawidłowych komórkach jednojądrzastych [20].

Wiele komórek wydziela S1P, który następnie może działać w mechanizmie auto- lub parakrynnym. W większości znanych działań S1P pośredniczy 5 receptorów (S1PR1-5) rodziny białka $\mathrm{G}$ (ryc. 2). Ostatnio wykazano, że S1P pełni również ważną rolę wewnątrzkomórkowo w infekcjach, 


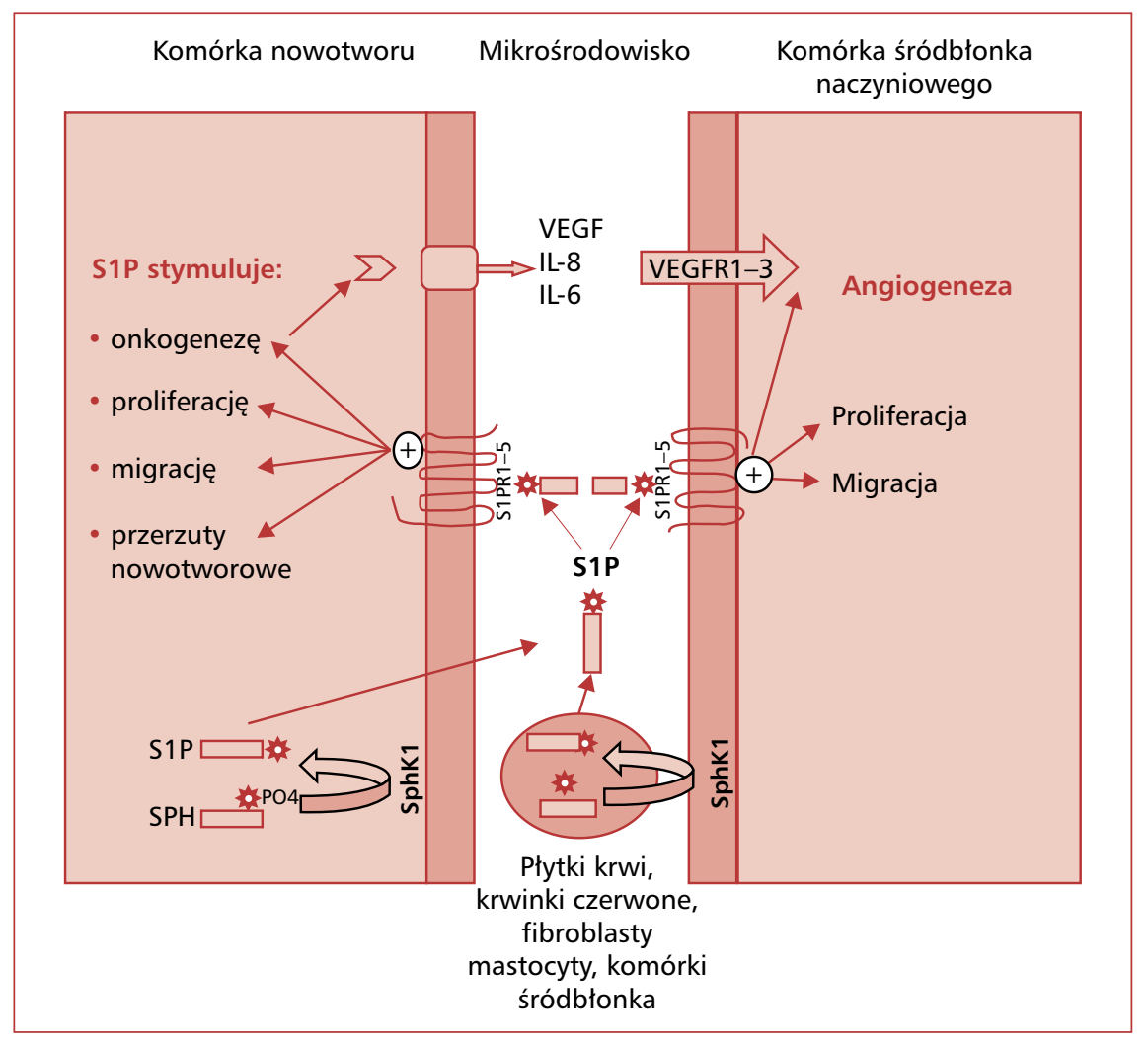

Rycina 2. Sfingozyno-1-fosforan (S1P) jest czynnikiem wzrostu komórki nowotworowej oraz naczyń. Komórki nowotworu zwiększają ekspresję enzymu sfingozynokinazy 1 (SphK1), która powoduje zwiększoną produkcję S1P. Z kolei S1P działa jako wtórny przekaźnik sygnałów wewnątrzkomórkowych, ale również poprzez aktywację należących do rodziny białek G błonowych receptorów sfingozyno 1-fosforanu (S1PR). Dotychczas wyizolowano pięć podtypów tych receptorów (S1PR1-5). Czynnik S1P może działać zarówno auto-, jak i parakrynnie na komórki nowotworu i komórki naczyń. Stymuluje onkogenezę, migrację komórek, zwiększając ich potencjał przerzutowy, a także działa pobudzająca na przeżycie komórki. Dodatkowo S1P promuje angiogenezę bezpośrednio poprzez aktywację receptora czynnika wzrostu śródbłonka naczyniowego (VEGFR) oraz pośrednio, ponieważ jest za uwalnianie czynnika wzrostu śródbłonka naczyniowego (VEGF) oraz interleukin (m.in. interleukiny 6 [IL-6] i interleukiny 8 [IL-8]); SPH — sfingomielina; PO4 — reszta fosforanowa

Figure 2. Sphingosine-1-phosphate (S1P) is a growth factor for cancer cells and blood vessels. Tumor cells increase the expression of the sphingosine kinase 1 enzyme (SphK1) which results in increased S1P production. S1P acts as a secondary transmitter of intracellular signals, and also through the activation of members of the $G$ protein family of the sphingosine 1 phosphate receptors (S1PR). Five subtypes of these receptors (S1PR1-5) have been isolated so far. S1P can act both auto and paracrine on tumor cells and vascular cells. It stimulates oncogenesis, cell migration, increasing their metastatic potential, and also stimulates cell survival. In addition, S1P promotes angiogenesis directly by activating the vascular endothelial growth factor receptor (VEGFR), and indirectly, it is responsible for the release of vascular endothelial growth factor (VEGF) and interleukin (among others: interleukin 6 [IL-6] and interleukin 8 [IL-8]); $\mathrm{SPH}$ - sphingomyelin; $\mathrm{PO} 4$ - phosphate residue

nowotworach i chorobie Alzheimera. To sugeruje, $\dot{z}$ e działania S1P są dużo bardziej złożone, niż wcześniej sądzono [8]. W ostatnich latach zidentyfikowano S1P jako jeden $z$ centralnych składników złożonego mikrośrodowiska ośrodków namnażania (GC, germinal centres) wtórnych narządów limfatycznych (SLO, secondry lymphoid organs), w których limfocyty B kończą dojrzewanie. Najistotniejszy w tym procesie, spośród 5 znanych receptorów
S1P, jest S1PR2. Promuje on tworzenie skupisk dojrzewających limfocytów B i ogranicza ich rozrost. Jest to możliwe poprzez ścieżkę sygnałową angażującą białka G (Ga12 i Ga13, małe GTPazy Rho i ich aktywator p115RhoGEF/ARHGEF1), które hamują wpływ lokalnych chemokin i czynników promujących przeżycie limfocytów B w GC SLO [21]. Sfingozyno-1-fosforan reguluje wiele procesów ważnych dla progresji nowotworu. Może także 
wplywać, poprzez bezpośrednie wiązanie, na wiele wewnątrzkomórkowych celów terapeutycznych, takich jak deacetylaza histonowa (HDAC, histone deacetylase), do wywołania regulacji epigenetycznej. Sfingozyno-1-fosforan jest zaangażowany w progresję nowotworu, w tym w transformację komórek/onkogenezę, przeżycie komórek/apoptozę, migrację komórek i ich przerzutowanie oraz neowaskularyzację mikrośrodowiska guza [21]. Wykazano, że ekspresja enzymu SphK1 jest zwiększona $\mathrm{w}$ wielu nowotworach, włączając w to białaczki, i wspólistnieje $z$ progresją nowotworu [22]. Wydaje się, że S1P jest czynnikiem stymulującym rozwój komórek nowotworowych, działającym stymulująco na angiogenezę, mastocyty oraz prawdopodobnie fibroblasty w mikrośrodowisku guza [23].

Co ważne, komórki nowotworowe zwiększają ekspresję SphK1, który może się w znacznym stopniu przyczynić do zwiększenia stężenia S1P w mikrośrodowisku guza. Wytworzony S1P jest w stanie działać autokrynnie lub parakrynnie w stosunku do komórek nowotworowych oraz naczyń: 1) promuje syntezę DNA i powoduje proliferację, 2) stymuluje migrację komórek, wzmacniając potencjał przerzutowy komórek guza 3) i chroni komórki nowotworu oraz komórki śródbłonka naczyń przed apoptozą wywołaną chemioterapeutykami. Jako dodatkowy efekt pośrednio angiogenny S1P jest odpowiedzialny za uwolnienie proangiogennych czynników wzrostu (czynnik wzrostu śródbłonka naczyniowego [VEGF, vascular endothelial growth factor], interleukinę 6 [IL-6] i interleukinę 6 [IL-8]) z komórek guza. Połączenie pronowotworowego i proangiogennego działania S1P powoduje, że jest on doskonałym celem terapii przeciwnowotworowej [23]. Proces angiogenezy, w którym powstają nowe naczynia krwionośne $z$ istniejącego układu naczyniowego związany $z$ angiogenezą nowotworów, uważa się za składnik progresji choroby. Leczenie antyangiogenne uważa się za istotne, ponieważ komórki śródbłonka naczyniowego nie mutują tak łatwo jak komórki nowotworowe, w związku $z$ tym rzadziej niż komórki nowotworowe uzyskują oporność na długotrwałą terapię, co czyni z nich dobry cel terapeutyczny. Kliniczną rolę antyangiogennej terapii nowotworu podkreśla zatwierdzenie przez amerykańską Agencję ds. Żywności i Leków (FDA, Food and Drug Administration) leku antyangiogennego, bewacyzumabu, $\mathrm{w}$ leczeniu chorych na raka jelita grubego [23].

Wielu autorów na podstawie wyników przeprowadzonych analiz sugeruje istotną rolę S1P w stymulacji rozwoju naczyń krwionośnych, wykazując jego działanie stymulujące na syntezę DNA i ruchliwość chemotaktyczną ludzkich komórek śródbłonka żyły pępowinowej (HUVEC, human umbilical vein endothelial cells) $[24,25]$. Porównanie proangiogennego działania S1P do dobrze znanych angiogennych czynników VEGF i podstawowego czynnika wzrostu fibroblastów (bFGF, basic fibroblast growth factor) wskazuje, że S1P działa jako jedna $z$ silniejszych substancji proangiogennych [23].

\section{Ceramid}

Ceramid uważa się za główny wtórny przekaźnik sfingomielinowego szlaku transmisji sygnałów o działaniu proapoptotycznym. Inicjuje liczne procesy patologiczne zależne od czynnika powodującego wzrost jego stężenia w komórce. Ceramid odpowiada za regulację różnych procesów komórkowych, takich jak proliferacja i różnicowanie komórkowe, programowana śmierć komórki, hamowanie wzrostu komórek czy starzenie się komórek [14, 26-31]. Tak szerokie biologiczne efekty działania tego związku wynikają ze zróżnicowania receptorów, na jakie działają czynniki powodujące zwiększenie jego zawartości w komórce. Molekularny mechanizm jego działania polega na aktywacji białek enzymatycznych. Głównymi aktywowanym przez ceramid białkami są specyficzna błonowa kinaza białkowa (CAPK, ceramide-activated protein kinase) oraz serynowo-treoninowa fosfataza białkowa (CAPP, ceramide-activated protein phosphatase). Inne kinazy białkowe, aktywowane przez ceramid, to kinaza białkowa aktywowana mitogenem (MAPK, mitogen activated protein kinase) i kinaza białkowa $\mathrm{C} \zeta$, a także kinazy aktywowane stresem, takie jak kinaza JNK (c-jun $N$-terminal protein kinase) [32, 33]. Metabolity ceramidu pełnią także funkcje wtórnych przekaźników, warunkując wiele procesów komórkowych. Działanie proapoptotyczne wiąże się $z$ aktywacją enzymów wykonawczych — kaspaz (kaspazy 3 i kaspazy 8), które powodują dezintegrację cytoszkieletu, błon biologicznych, a także jądra komórkowego [34]. Prowadzi to do uwolnienia reaktywnych form tlenu (ROS, reactive oxygen species) i mitochondrialnego cytochromu c. Udział ceramidu w indukcji procesu apoptozy wiąże się $z$ supresją antyapoptotycznych białek Bcl-2 (B-cell lymphoma 2 ) oraz hamowaniem kinazy białkowej $\mathrm{B}(\mathrm{PKB}$, protein kinase $B)$, zwanej też AKT, oraz kinazą białkową $\mathrm{C} \alpha(\mathrm{PKC} \alpha$, protein kinase $C \alpha$ ) [35]. Może on działać również za pośrednictwem proteazy apoptotycznej katepsyny D. Podwyższone stężenie komórkowego ceramidu, poprzedzające wystąpienie apoptozy, jest związane $\mathrm{z}$ aktywacją receptorów rodziny $\mathrm{TNF} \alpha$. Ceramid ma 
też zdolność aktywacji proapoptotycznych kinaz białkowych JNK [34]. Również w liniach komórek mieloidalnych i limfoidalnych, poddanych działaniu ceramidu, obserwowano fragmentację DNA, co uznawano za wykładnik procesu apoptozy [36].

Wzrost komórkowego stężenia ceramidu powoduje zahamowanie podziałów komórkowych, proliferacji i wzrostu komórek, czego dowiedziono w hodowlach linii komórkowych Molt-4 (ludzkie komórki białaczki limfoblastycznej T-komórkowej [T-ALL, T-cell acute lymphoblastic leukemia]). Usunięcie czynników wzrostu spowodowało aktywację sfingomielinazy obojętnej oraz kilkunastokrotny wzrost stężenia ceramidu. W 80\% przypadków obserwowano zatrzymanie cyklu komórkowego między fazami G0-G1 [37].

\section{Rola sfingolipidów i ich enzymów metabolicznych w nowotworach hematologicznych}

\section{Ostre białaczki}

Substancje przeciwbiałaczkowe zwiększają stężenie ceramidu w komórkach nowotworowych. Stosowany w leczeniu ostrej białaczki promielocytowej trójtlenek arsenu zwiększa stężenie ceramidu poprzez aktywację syntezy ceramidu de novo oraz hamowanie syntazy glucozylceramidu (GCS, glucosylceramide). Leczenie syntetycznym retinoidem indukuje śmierć komórki poprzez wzrost stężenia dihydroceramidu w komórce, ale jednocześnie zahamowanie jego syntezy de novo przez myriocin (aminokwas pochodzący z grzybów termofilnych, w tym przypadku sterylnej grzybni Mycelia sterilia). Silny środek immunosupresyjny, prekursor leku o nazwie fingolimod, nie wpływa na zmniejszenie żywotności komórki nawet przy spadku zawartości dihydroceramidu. Obserwacje te sugerują konieczność prowadzenia dalszych badań nad wytłumaczeniem funkcji i regulacji śmierci komórki przez ceramidy [38].

Stężenie cząstek bioaktywnych sfingolipidowego szlaku sygnałowego $\mathrm{w}$ osoczu chorych na AML znacząco różni się od stężenia u osób zdrowych. Średnie stężenie w osoczu krwi chorych sfingozyny, sfinganiny i ceramidu jest istotnie wyższe, natomiast stężenie S1P — znacząco niższe. W tym samym czasie stosunek ceramidu/S1P u pacjentów z AML $(44,5 \pm 19,4)$ jest o około $54 \%$ wyższy niż w grupie kontrolnej $(20,9 \pm 13,1)$, co sugeruje ich wpływ na rozwój i przebieg choroby [16]. We wcześniejszych badaniach wykazano, że inhibitor pan-SphK, inhibitor kinaz sfingozynowych DMS (N, N-dimethylsphingosine), znacząco zwiększa apoptozę komórek U937 (z ang. human leukemic monocyte lymphoma cell line) i komórek Jurkat (unieśmiertelnionych komórek linii ostrej białaczki z limfocytów T). W 72-godzinnej hodowli komórek U937 stwierdzono znaczące zahamowanie wzrostu przy stosunkowo niskim stężeniu inhibitora. Komórki Jurkat okazały się jeszcze bardziej wrażliwe na obecność inhibitora SphK, co spowodowało 50-procentowe spowolnienie wzrostu komórek $\mathrm{w}$ hodowli. Podobny efekt uzyskano w badaniu innych białaczkowych linii komórkowych, w tym promielocytowej HL-60, Molt-4 białaczki T-komórkowej i komórek K-562 CML (ludzka unieśmiertelniona linia komórkowa białaczki szpikowej, typu erytroleukemicznego, pochodząca od 53-letniej pacjentki z przewlekłą białaczką szpikową [CML, chronic myelogenous leukemia] $\mathrm{w}$ fazie przełomu blastycznego de novo) [22]. Inhibitor kinazy sfingozyny 1 (Sk1-I) BML-258 nie tylko obniża stężenie $\mathrm{S} 1 \mathrm{P}$, ale również zwiększa stężenie jego proapoptotycznego prekursora, ceramidu. I odwrotnie; S1P chroni przed indukowaną apoptozą. Inhibitor kinazy sfingozyny 1 silnie indukuje apoptozę $\mathrm{w}$ blastach białaczkowych izolowanych od pacjentów z AML, ale jest relatywnie mniej aktywny w prawidłowych mononuklearach $z$ krwi pacjentów. Ponadto w obserwacji ksenograftu guza AML stwierdzono znaczące ograniczenie wzrostu pod wpływem Sk1-I. Rezultaty sugerują, że specyficzne inhibitory SphK1 zwracają przynajmniej uwagę jako potencjalny dodatek do leków przeciwbiałaczkowych [22]. Oceniając wpływ 24-godzinnej ekspozycji SkI-1 na blasty białaczkowe pobrane od 2 pacjentów z AML (FAB podtyp M2), badacze wykazali znaczący wzrost apoptozy [22].

W ostrej T-ALL S1P hamuje klasyczną apoptozę komórek [39]. FTY720 (fingolimod) działający przez receptory S1P indukuje autofagocytozę. Stężenie SphK1 jest zwiększone w ostrej białaczce limfoblastycznej B-komórkowej (B-ALL, B-cell acute lymphoblastic leukemia) [40]. Aktywność przeciwbiałaczkową SkI-1 oceniano również, badając hamowanie wzrostu ksenograftu komórek ostrej białaczki u immunoniekompetentnych myszy SCID/beige. Stwierdzono znaczące, o około $50 \%$, zahamowanie wzrostu guzów u myszy leczonych SkI-1 [22]. Receptor S1PR1 ma kluczowe znaczenie w progresji różnych typów guzów litych poprzez pozytywną regulację antyapoptotyczna/ /proproliferacyjną przez sygnalizację S1P-S1PR1. Rola S1PR1 w progresji AML pozostaje jednak nie do końca wyjaśniona. Xu i wsp. [41] przy użyciu testu nadekspresji i testu interferencji RNA dowiedli, że ekspresja S1PR1 w kilku li- 
niach komórkowych ludzkiej białaczki szpikowej przyczyniła się do zahamowania apoptozy komórkowej i promocji proliferacji komórek. Receptor S1PR1 zahamował ekspresję białka X związanego $z$ chłoniakiem $z$ limfocytów B (promotor apoptozy związany $z$ mitochondriami) i zapobiegal rozszczepieniu kaspazy 3, co wskazuje, że S1PR1 zakłócał procesy apoptotyczne związane $z$ mitochondriami w komórkach AML. Stymulacja S1PR1 tłumiła wytwarzanie ROS w komórkach AML, a apoptozę, w której pośredniczyła negatywna regulacja S1PR1, częściowo odwrócono przez ekspozycję na N-acetylo-L-cysteinę i wychwytywanie ROS, co sugeruje, że wywołana przez S1PR1 oporność apoptozy komórkowej wynikała, przynajmniej częściowo, z ograniczenia generowania ROS. Dodatkowo S1PR1 był zdolny do zakłócania sygnalizacji kinazy JNK, co również może się przyczyniać do supresji apoptozy komórkowej. Natomiast sygnalizacja szlaku kinaz regulowanych zewnątrzkomórkowo (ERK, extracellular signal-regulated kinases) przeciwnie - wydawała się pozytywnie modulowana przez indukowane przez S1PR1 wzmocnienie aktywacji MAPK1 (MKK1), co sugeruje, że S1PR1 może promować przeżycie i proliferację komórek poprzez wzmacnianie sygnalizacji MKK1-ERK. Prawdopodobnie S1PR1 służy więc jako antyapoptotyczne/proproliferacyjne białko w komórkach AML poprzez hamowanie apoptozy związanej $z$ mitochondrium i generowania ROS oraz poprzez regulację wielu kaskad sygnalizacyjnych MAPK [41].

\section{Przewlekła białaczka szpikowa}

Wykazano również, że S1P w CML podwyższa stężenie antyapoptotycznego białka Mcl-1 (myeloid cell leukemia-1), białka rodziny białek programowanej śmierci komórki Bcl-2 [42], a jego wiązanie $z$ receptorem typu 2, S1P (S1PR2), hamuje defosforylację $\mathrm{BCR} / \mathrm{ABL} 1$ zależną od fosfatazy białkowej 2A (PP2A, protein phosphatase 2A) [43]. Ekspresja enzymu SphK1 jest zwiększana przez BCR/ABL1 i odwrotnie [44]. Tian i Yu [45], badając wpływ resweratrolu na indukowanie apoptozy komórek białaczki K562 (linia komórkowa ludzkiej CML), wykazali, że substancja ta indukuje apoptozę komórek poprzez modulację szlaku S1P — hamowanie SphK. Leczenie resweratrolem znacząco hamuje działanie SphK. W badaniach udowodniono, że SphK1 działa jako onkogen i nadekspresja SphK1/ /S1P może indukować wzrost guza i hamować zależną od ceramidu apoptozę, co prowadzi do oporności na leki w przebiegu wielu nowotworów, w tym białaczek [45].
Kiedy komórki AML i CML stają się oporne na chemioterapię, to aktywność syntazy sfingomieliny (SMS, sphingomyelin synthase) i syntazy glukozyloceramidu znacząco wzrasta w stosunku do komórek chemiowrażliwych, co prowadzi do zmniejszenia zależnej od ceramidu śmierci komórki [38].

\section{Szpiczak plazmocytowy}

W PCM rolą S1P jest ochrona przed indukowaną deksametazonem cytotoksycznością przez zwiększenie stężenia MCL-1 (unikatowe, krótko żyjące białko - członek rodziny BCL-2 może także funkcjonować jako czynnik stymulujący apoptozę, który powstaje w wyniku alternatywnego składania jego pre-mRNA, potranslacyjnych modyfikacji czy proteolizy) oraz przez szlaki sygnałowe ERK i AKT [46]. Aktywacja SphK1przez IL-6 skutkuje proliferacją komórek [40]. Dla progresji PCM istotna jest adhezja plazmocytów zależna od integryny $\alpha 4 \beta_{1}$, która jest regulowana przez chemokinę CXCL12 (SDF-1, stromal cell-derived factor 1). Farmakologiczna blokada receptora CXCR4 (receptora CXCL12) prowadzi do zaburzenia przylegania plazmocytów w szpiku kostnym. Komórki szpiczaka mają receptor S1PR1 dla S1P. Wykazano, że S1P zwiększa adhezję komórek szpiczaka, w której pośredniczy integryna $\alpha 4 \beta_{1}$, oraz przezśródbłonkową migrację komórek szpiczaka stymulowaną przez CXCL12. Analiza in vivo wykazała dodatni wpływ S1P na osiedlanie się komórek szpiczaka w szpiku kostnym i ich interakcji z mikrośrodowiskiem. Regulacja $\alpha 4 \beta_{1}$-zależnej adhezji i migracji komórek przez współdziałanie chemokiny CXCL12 oraz S1P może mieć zatem istotne konsekwencja dla progresji PCM [47].

\section{Chłoniaki}

Zwiększenie stężenia antyapoptotycznego MCL-1 przez S1P oraz nasilenie ekspresji S1PR1 stwierdzono również $\mathrm{w}$ chłoniaku z komórek płaszcza (MCL, mantle cell lymphoma) [48]. Badając linie komórkowe rozlanego chłoniaka $z$ dużych komórek B (DLBCL, diffuse large B-cell lymphoma) inkubowane $\mathrm{w}$ obecności sfingozyny i L-treo-sfingozyny metodami cytometrii przepływowej, testu immunoenzymatycznego (ELISA, enzyme-linked immunosorbent assay test), wysokosprawnej chromatografii cieczowej (HPLC, high-performance liquid chromatography) oraz testów Western-blot, Bode i wsp. [49] wykazali, że sfingozyna indukuje śmierć komórek i hamuje ich wzrost niezależnie od receptorów S1P. Zaobserwowali trzy różne rodzaje śmierci mediowanej przez sfingozynę, autofagocytozę, apoptozę oraz 
hamowanie PKC, a generacja proapoptotycznego ceramidu tłumaczy ich mniejszą część [49]. Rytuksymab, istotny czynnik immunoterapii chłoniaków $\mathrm{z}$ komórek B - ludzko-mysie przeciwciało monoklonalne anty-CD20 - wywoluje zahamowanie cyklu komórkowego i wzrostu komórek drogą indukcji p27Kip1 (cyclin-dependent kinase inhibitor $1 B$ ) poprzez wzrost stężenia ceramidu $\mathrm{w}$ wyniku aktywacji sfingomielinaz $\mathrm{w}$ tratwach lipidowych błon komórkowych [38]. Niedobór, mutacje receptora S1PR2 odgrywają istotną rolę w rozwoju DLBCL wywodzącego się z ośrodków rozmnażania (GCB-DLBCL, germinal center $B$-cell like DLBCL). W badaniach na myszach S1PR2-/$z$ utratą hamowania wzrostu limfocytów B w GC SLO i ich niekontrolowanym rozrostem wykazano, że skutkuje to rozwojem podobnego do ludzkiego chłoniaka GCB-DLBCL. Podobny fenotyp u myszy pozbawionych mediatorów sygnałowych S1PR2 Ga13 czy p115RhoGEF, jak również z obecnością inaktywujących mutacji w odpowiednich genach (GNA13 i RHGEF1) kodujących cząstki sygnałowe S1PR2 z rozpoznaniem GCB-DLBCL potwierdza rolę niedoboru S1PR2 w rozwoju tego nowotworu. Co ciekawe, w gorzej rokującym DLBCL $\mathrm{Z}$ aktywowanych komórek B (ABC-DLBCL, activated $B$ cell-like $D L B C L$ ) nie stwierdzono mutacji S1PR2. Wykryto natomiast mechanizm alternatywny inaktywacji S1PR2, obejmujący wyciszanie genów kodujących cząstki sygnałowe przez niezwykle wysokie stężenie czynnika transkrypcyjnego FOXP1 (Forkhead box-P1), powodujące deregulację osi hamującej rozrost limfocytów B i kontrolującej programowaną śmierć [21]. Niska ekspresja S1PR2 w ABC-DLBCL jest silnym negatywnym czynnikiem prognostycznym przeżycia pacjenta bez leczenia, a zwłaszcza w połączeniu Z wysoką ekspresją FOXP1 [50]. Analiza Koresawa i wsp. [51] dowiodła nadekspresji S1PR1 w $15,7 \%$ wszystkich przypadków DLBCL i $54,2 \%$ spośród 24 przypadków chorych z pierwotnym chłoniakiem DLBCL jąder (PT-DLBCL, primary testicular DLBCL). Ekspresja S1PR1 korelowała z ekspresją mRNA S1PR1 i fosforylacją STAT3 (signal transducer and activator of transcription 3). Analiza danych sugeruje, że nadekspresja S1PR1 była niezależnym negatywnym markerem prognostycznym u 68 pacjentów z DLBCL w stadiach klinicznych I i II. Obecna wysoka częstość występowania nadekspresji S1PR1 gwarantuje rozważenie PT-DLBCL jako odrębnego podtypu choroby i sugeruje potencjał osi S1P/S1PR1 jako celu terapeutycznego w tym rozpoznaniu [51].

\section{Perspektywy w terapii nowotworów z zastosowaniem substancji sfingomielinowego szlaku transmisji sygnału}

Na podstawie przeprowadzonych licznych analiz uznano, że bioaktywne lipidy jako cząsteczki sygnalizacyjne mogą się stać potencjalnym celem terapeutycznym [23]. Analizowano na przykład potencjał terapeutyczny SkI, inhibitora kinazy sfingozyny 1 oraz 2 , a także ROMe, selektywnego inhibitora Sk2. W modelach in vitro SkI indukował apoptozę, natomiast ROMe inicjował śmierć komórki w mechanizmie autofagii; SkI indukowal wzrost SphK1 w komórkach Molt-4. Badacze zaobserwowali synergistyczny efekt SkI z klasyczną chemioterapią winkrystyną. Uzyskane wyniki wskazują na SphK1 oraz SphK2 jako potencjalne cele terapeutyczne w T-ALL [52].

Wyniki badań $z$ użyciem nowego inhibitora kinazy AKT, A-674563, wykazują zależne od dawki zahamowanie wzrostu i proliferacji komórek U937 w AML i sześciu linii ludzkich komórek progenitorowych AML; A-674563 aktywował kaspazy 3/9 i powodował apoptozę komórek AML. Ponadto A-674563 obniżał aktywność SphK1 w komórkach białaczki, zmniejszając prożyciowy S1P i wzmagając produkcję proapoptycznego ceramidu. To działanie było niezależne od blokowania szlaku AKT. Co ważne, dootrzewnowe iniekcje A-674563 u nagich myszy, w dobrze tolerowanych dawkach, hamowały wzrost ksenograftów komórek U937, co znacznie poprawiło przeżywalność zwierząt. Wyniki tego badania demonstrują, że A-674563 wykazuje aktywność przeciwbiałaczkową in vitro oraz in vivo, prawdopodobnie w wyniku równoległego działania poprzez drogi sygnałowe AKT i SphK1 [53].

W badaniu Powell i wsp. [20] podawanie inhibitorów SphK1 i 2 (MP-A08) do ortotopowych ksenoprzeszczepów pochodzących od chorych na AML zmniejszało obciążenie nowotworem i przedłużało całkowite przeżycie bez wpływu na hematopoezę myszy. Hamowanie SphK1 wiązało się ze zmniejszoną sygnalizacją przeżycia z S1PR2, co skutkowało selektywną negatywną regulacją ekspresji białka MCL-1. Późniejsza analiza dowiodła, że połączenie mimetyków BH3 (białka rodziny proapoptycznych cząsteczek BCL-2) z hamowaniem Sphk1 lub antagonizmem receptora S1PR2 wyzwala synergistyczną śmierć komórek AML. Wyniki te według autorów potwierdzają pogląd, że SphK1 jest prawdziwym celem terapeutycznym w leczeniu AML [20]. 
Ponadto Tan i wsp. [54] wykazali, że pierwotne komórki AML cechuje wysoki poziom ekspresji i aktywności ceramidazy kwaśnej (AC, acid ceramidase), która katalizuje rozkład ceramidu do sfingozyny, prekursora S1P. Ekspozycja próbek pacjentów i linii komórkowych na inhibitor AC LCL204 zmniejszała żywotność komórek i indukowało apoptozę. Nadekspresja AC zwiększyła ekspresję antyapoptotycznego MCL-1, znacząco zwiększała stężenie S1P i zmniejszała stężenie ceramidu. I odwrotnie; LCL204 indukował akumulację ceramidu i zmniejszał ekspresję MCL-1 poprzez mechanizmy potranslacyjne.

Traktowanie LCL204 myszy NSG C57BL/6 zaszczepionych pierwotnymi ludzkimi komórkami białaczkowymi C1498 znacząco zwiększało całkowity czas przeżycia myszy i znacząco zmniejszyło masę guza (białaczkowego) u tych zwierząt. Autorzy sugerują, że AC odgrywa kluczową rolę w przeżyciu w AML poprzez regulację wartości sfingolipidów i MCL-1 i proponują prowadzenie dalszych badań nad możliwością wykorzystania AC jako nowego celu terapeutycznego w AML [54].

Prowadzone są również badania nad konsekwencjami współdziałania CXCR4/CXCL12 $z$ drogą sygnałową S1P w PCM, a także nad użyciem FTY720 jako potencjalnego modulatora w terapii przeciwszpiczakowej [55]. Toczy się wiele badań przedklinicznych służących badaniu wpływu FTY720 na nowotwory hematologiczne [40]. Fingolimod (FTY720) wprowadzony do leczenia stwardnienia rozsianego jest pierwszym klinicznie terapeutykiem wykorzystującym w mechanizmie swego działania wpływ na transmisje sygnału szlaku sfingomielinowego. $Z$ kolei FTY720P jest analogiem sfingozyny, agonistą receptora S1PR1. Niedawno zaobserwowano aktywność przeciwnowotworową i proapoptotyczną FTY720P (aktywna forma FTY720) na komórki białaczki AML-M2. Wcześniej wykazano jego aktywność w innych nowotworach hematologicznych, takich jak przewlekła białaczka limfatyczna/chłoniak limfocytarny, białaczka $z$ komórek naturalnej cytotoksyczności (NK, natural killer), białaczka $z$ dużych ziarnistych limfocytów (T-LGL, large granular lymphocytic leukemia), CML i ALL z obecnością chromosomu Filadelfia $(\mathrm{Ph}+$, Philadelfia-positive) oraz $\mathrm{AML}$ $z$ mutacją c-KIT [56]. Kombinacja FTY720 z inhibitorem SphK1 wykazuje synergistyczne zahamowanie wzrostu komórek szpiczaka. Zwiększona ekspresja CXCR4/CXCL12 w komórkach szpiczaka koreluje $z$ ich zmniejszoną wrażliwością na inhibitory (FTY720 oraz SphK1 inhibitor), co sugeruje przenikanie ścieżek CXCR4/CXCL12 i SphK1 w komórkach PCM [55]. W modelach przedklinicznych allo-HSCT modulacja S1PR za pośrednictwem FTY720 hamowała chorobę przeszczep przeciw gospodarzowi (GvHD, graft-versus-host disease), a jednocześnie pozwalała na korzystny efekt przeszczepu przeciwko białaczce (GvL, graft-versus-leukemia). To oddzielenie reakcji GvHD i GvL przez FTY720 wynikało $z$ faktu, że aktywność GvHD była utrzymywana i ograniczona do układów chłonnego i krwiotwórczego. Inny potencjalny mechanizm skutecznego efektu GvL $z$ modulatorami S1P może wynikać ze zróżnicowanego efektu limfocytach $\mathrm{w}$ porównaniu $\mathrm{z}$ komórkami NK (istotnym elemencie układu odpornościowego dla GvL).

Ostatnie dane sugerują ważną rolę sygnalizacji S1P w przeszczepianiu, GvHD, GvL i innych procesach, które występują podczas i po przeszczepieniu krwiotwórczych komórek macierzystych. Na podstawie takich danych interwencja farmakologiczna poprzez modulację S1P może mieć potencjał poprawy wyników pacjenta poddanego przeszczepieniu poprzez regulację GvHD i polepszenie wszczepienia, umożliwiając jednocześnie skuteczny efekt GvL [57]. Sfingozyna i jej analogi mogą być brane pod uwagę jako alternatywne opcje w leczeniu agresywnych chłoniaków poprzez wpływ na apoptozę, autofagię oraz hamowanie PKC. Ta fizjologiczna odpowiedź na różne wewnątrzkomórkowe szlaki sygnałowe identyfikuje sfingozynę jako potencjalny czynnik indukujący śmierć komórki [35].

Ozanimod i siponimod, funkcjonalni antagoniści S1PR1, mogący blokować aktywację AKT $z$ udziałem S1P, są już w fazach II i III badaniach klinicznych pacjentów $z$ chorobami zapalnymi i autoimmunizacyjnymi. Te i inne modulatory S1PR1 powinny być badane pod kątem ich potencjału terapeutycznego w chłoniaku Hodgkina (HL, Hodgkin lymphoma). Blokada terapeutyczna sygnalizacji S1P może hamować działanie onkogenne czynnika transkrypcyjnego BATF3 (basic leucine zipper ATF-like transcription factor 3). Ekspresja BATF3 ulega nadekspresji w komórkach HL. W prawidłowych limfocytach ekspresja ogranicza się do niewielkiej frakcji immunoblastów CD30+; BATF3 w komórkach HL powoduje nadekspresję receptora S1PR1, za pośrednictwem którego S1P aktywuje szlak 3-kinazy fosfatydyloinozytolu (PI3K, phosphatidylinositol 3-kinase) oraz zmniejsza ekspresję S1PR2. Blokada S1P hamuje efekt onkogenny BATF3 w komórkach HL [58].

Użycie przeciwciał monoklonalnych anty-S1P jest leczeniem skierowanym przeciwko S1P, który ma wiele mechanizmów działania promujących rozwój nowotworu - bezpośredni wpływ 
S1P na wzrost guza i jego potencjał przerzutowy, bezpośredni efekt angiogenny oraz pośredni efekt angiogenny stymulujący uwalnianie i działanie innych substancji zwiększających tworzenie naczyń włosowatych, takich jak VEGF i bFGF. Na tej podstawie można przewidywać wprowadzenie do leczenia różnych przeciwciał o typie sphingo-mab, których rozwój będzie możliwy dzięki postępom lipidomiki [56].

\section{Piśmiennictwo}

1. Ogretmen B, Hannun YA. Biologically active sphingolipids in cancer pathogenesis and treatment. Nat Rev Cancer. 2004; 4(8): 604-616, doi: 10.1038/nrc1411, indexed in Pubmed: 15286740.

2. Kolesnick RN. 1,2-Diacylglycerols but not phorbol esters stimulate sphingomyelin hydrolysis in GH3 pituitary cells. J Biol Chem. 1987; 262(35): 16759-16762, indexed in Pubmed: 3479432.

3. Kolesnick RN. Thyrotropin-releasing hormone and phorbol esters induce phosphatidylcholine synthesis in GH3 pituitary cells. Evidence for stimulation via protein kinase C. J Biol Chem. 1987; 262(30): 14525-14530, indexed in Pubmed: 3117787.

4. Kolesnick RN, Paley AE. 1, 2-Diacylglycerols and phorbol esters stimulate phosphatidylcholine metabolism in GH3 pituitary cells. Evidence for separate mechanisms of action. J Biol Chem. 1987; 262(19): 9204-9210, indexed in Pubmed: 3597411.

5. Watters RJ, Wang HG, Sung SS, et al. Targeting sphingosine-1-phosphate receptors in cancer. Anticancer Agents Med Chem. 2011; 11(9): 810-817, doi: 10.2174/187152011797655041.

6. Huang WC, Chen CL, Lin YS, et al. Apoptotic sphingolipid ceramide in cancer therapy. J Lipids. 2011; 2011: 565316, doi: 10.1155/2011/565316, indexed in Pubmed: 21490804.

7. Brizuela L, Ader I, Mazerolles C, et al. First evidence of sphingosine 1-phosphate lyase protein expression and activity downregulation in human neoplasm: implication for resistance to therapeutics in prostate cancer. Mol Cancer Ther. 2012; 11(9): 1841-1851, doi: 10.1158/1535-7163.MCT-12-0227, indexed in Pubmed: 22784711.

8. Liu Y, Deng J, Wang L, et al. S1PR1 is an effective target to block STAT3 signaling in activated B cell-like diffuse large B-cell lymphoma. Blood. 2012; 120(7): 1458-1465, doi: 10.1182/ /blood-2011-12-399030, indexed in Pubmed: 22745305.

9. Sanna MG, Liao J, Jo E, et al. Sphingosine 1-phosphate (S1P) receptor subtypes S1P1 and S1P3, respectively, regulate lymphocyte recirculation and heart rate. J Biol Chem. 2004; 279(14): 13839-13848, doi: 10.1074/jbc.M311743200, indexed in Pubmed: 14732717.

10. Shimizu T. Lipid mediators in health and disease: enzymes and receptors as therapeutic targets for the regulation of immunity and inflammation. Annu Rev Pharmacol Toxicol. 2009; 49: 123-150, doi: 10.1146/annurev.pharmtox.011008.145616, indexed in Pubmed: 18834304.

11. Clarke CJ, Wu BX, Hannun YA. The neutral sphingomyelinase family: identifying biochemical connections. Adv Enzyme Regul. 2011; 51(1): 51-58, doi: 10.1016/..advenzreg.2010.09.016, indexed in Pubmed: 21035485.

12. Hammad SM. Blood sphingolipids in homeostasis and pathobiology. Adv Exp Med Biol. 2011; 721: 57-66, doi: 10.1007/978-14614-0650-1_4, indexed in Pubmed: 21910082.
13. Hannun YA, Obeid LM. Principles of bioactive lipid signalling: lessons from sphingolipids. Nat Rev Mol Cell Biol. 2008; 9(2): 139-150, doi: 10.1038/nrm2329, indexed in Pubmed: 18216770.

14. Ohanian J, Ohanian V. Sphingolipids in mammalian cell signalling. Cell Mol Life Sci. 2001; 58(14): 2053-2068, doi: 10.1007/ /PL00000836, indexed in Pubmed: 11814056.

15. Gault CR, Obeid LM, Hannun YA. An overview of sphingolipid metabolism: from synthesis to breakdown. Adv Exp Med Biol. 2010; 688: 1-23, indexed in Pubmed: 20919643.

16. Wątek M, Durnaś B, Wollny T, et al. Unexpected profile of sphingolipid contents in blood and bone marrow plasma collected from patients diagnosed with acute myeloid leukemia. Lipids Health Dis. 2017; 16(1): 235, doi: 10.1186/s12944-017-0624-1, indexed in Pubmed: 29216917.

17. Cuvillier O, Levade T. Sphingosine 1-phosphate antagonizes apoptosis of human leukemia cells by inhibiting release of cytochrome $\mathrm{c}$ and Smac/DIABLO from mitochondria. Blood. 2001; 98(9): 2828-2836, indexed in Pubmed: 11675357.

18. Rodriguez-Lafrasse C, Alphonse G, Aloy MT, et al. Increasing endogenous ceramide using inhibitors of sphingolipid metabolism maximizes ionizing radiation-induced mitochondrial injury and apoptotic cell killing. Int J Cancer. 2002; 101(6): 589-598, doi: 10.1002/ijc.10652, indexed in Pubmed: 12237902.

19. Bonhoure E, Pchejetski D, Aouali N, et al. Overcoming MDR-associated chemoresistance in HL-60 acute myeloid leukemia cells by targeting sphingosine kinase-1. Leukemia. 2006; 20(1): 95-102, doi: 10.1038/sj.leu.2404023, indexed in Pubmed: 16281067.

20. Powell JA, Lewis AC, Zhu W, et al. Targeting sphingosine kinase 1 induces MCL1-dependent cell death in acute myeloid leukemia. Blood. 2017; 129(6): 771-782, doi: 10.1182/blood-2016-06-720433, indexed in Pubmed: 27956387.

21. Baldari CT. S1PR2 deficiency in DLBCL: a FOXy connection. Blood. 2016; 127(11): 1380-1381, doi: 10.1182/ /blood-2016-01-692129, indexed in Pubmed: 26989186.

22. Paugh SW, Paugh BS, Rahmani M, et al. A selective sphingosine kinase 1 inhibitor integrates multiple molecular therapeutic targets in human leukemia. Blood. 2008; 112(4): 1382-1391, doi: 10.1182/ /blood-2008-02-138958, indexed in Pubmed: 18511810.

23. Sabbadini RA. Targeting sphingosine-1-phosphate for cancer therapy. Br J Cancer. 2006; 95(9): 1131-1135, doi: 10.1038/ /sj.bjc.6603400, indexed in Pubmed: 17024123.

24. Lee OH, Kim YM, Lee YM, et al. Sphingosine 1-phosphate induces angiogenesis: its angiogenic action and signaling mechanism in human umbilical vein endothelial cells. Biochem Biophys Res Commun. 1999; 264(3): 743-750, doi: 10.1006/bbrc.1999.1586, indexed in Pubmed: 10544002.

25. Argraves KM, Wilkerson BA, Argraves WS, et al. Sphingosine-1-phosphate signaling promotes critical migratory events in vasculogenesis. J Biol Chem. 2004; 279(48): 50580-50590, doi: 10.1074/jbc.M404432200, indexed in Pubmed: 15377653.

26. Wang G, Silva J, Krishnamurthy K, et al. Direct binding to ceramide activates protein kinase Czeta before the formation of a pro-apoptotic complex with PAR-4 in differentiating stem cells. J Biol Chem. 2005; 280(28): 26415-26424, doi: 10.1074/jbc. M501492200, indexed in Pubmed: 15901738.

27. Kolesnick R, Fuks Z. Radiation and ceramide-induced apoptosis. Oncogene. 2003; 22(37): 5897-5906, doi: 10.1038/sj.onc.1206702, indexed in Pubmed: 12947396.

28. Castillo SS, Levy M, Thaikoottathil JV, et al. Reactive nitrogen and oxygen species activate different sphingomyelinases to induce apoptosis in airway epithelial cells. Exp Cell Res. 2007; 313(12): 2680-2686, doi: 10.1016/j.yexcr.2007.04.002, indexed in Pubmed: 17498692. 
29. Hetz CA. Caspase-dependent initiation of apoptosis and necrosis by the Fas receptor in lymphoid cells: onset of necrosis is associated with delayed ceramide increase. J Cell Sci. 2002; 115(23): 4671-4683, doi: 10.1242/jcs.00153.

30. Oh JiE, So KS, Lim SeJ, et al. Induction of apoptotic cell death by a ceramide analog in PC-3 prostate cancer cells. Arch Pharm Res. 2006; 29(12): 1140-1146, indexed in Pubmed: 17225464.

31. MacRae VE, Burdon T, Ahmed SF, et al. Ceramide inhibition of chondrocyte proliferation and bone growth is IGF-I independent. J Endocrinol. 2006; 191(2): 369-377, doi: 10.1677/joe.1.06958, indexed in Pubmed: 17088406.

32. Bartke N, Hannun YA. Bioactive sphingolipids: metabolism and function. J Lipid Res. 2009; 50(Suppl): S91-S96, doi: 10.1194/jlr. R800080-JLR200, indexed in Pubmed: 19017611.

33. Dobrzyn A, Chocian G. Sfingomielinowy szlak transmisjii sygnalow. Med Metabol. 2003; 7(1): 75-80.

34. Morales A, Lee H, Goñi FM, et al. Sphingolipids and cell death. Apoptosis. 2007; 12(5): 923-939, doi: 10.1007/s10495-007-0721-0, indexed in Pubmed: 17294080.

35. Hearps AC, Burrows J, Connor CE, et al. Mitochondrial cytochrome $\mathrm{c}$ release precedes transmembrane depolarisation and caspase-3 activation during ceramide-induced apoptosis of Jurkat T cells. Apoptosis. 2002; 7(5): 387-394, indexed in Pubmed: 12207171.

36. Mullen TD, Obeid L. Ceramide and apoptosis: exploring the enigmatic connections between sphingolipid metabolism and programmed cell death. Anticancer Agents Med Chem. 2012; 12(4): 340-363, doi: 10.2174/187152012800228661.

37. Jayadev S, Liu B, Bielawska AE, et al. Role for ceramide in cell cycle arrest. J Biol Chem. 1995; 270(5): 2047-2052, indexed in Pubmed: 7836432.

38. Kitatani K, Taniguchi M, Okazaki T. Role of sphingolipids and metabolizing enzymes in hematological malignancies. Mol Cells. 2015; 38(6): 482-495, doi: 10.14348/molcells.2015.0118, indexed in Pubmed: 25997737.

39. Cuvillier O, Nava VE, Murthy SK, et al. Sphingosine generation, cytochrome c release, and activation of caspase-7 in doxorubicin-induced apoptosis of MCF7 breast adenocarcinoma cells. Cell Death Differ. 2001; 8(2): 162-171, doi: 10.1038/sj.cdd.4400793, indexed in Pubmed: 11313718.

40. Wallington-Beddoe CT, Bradstock KF, Bendall LJ. Oncogenic properties of sphingosine kinases in haematological malignancies. Br J Haematol. 2013; 161(5): 623-638, doi: 10.1111/bjh.12302, indexed in Pubmed: 23521541.

41. Xu XQ, Huang CM, Zhang YF, et al. S1PR1 mediates anti-apoptotic/pro-proliferative processes in human acute myeloid leukemia cells. Mol Med Rep. 2016; 14(4): 3369-3375, doi: 10.3892/ /mmr.2016.5629, indexed in Pubmed: 27572094.

42. Bednarek J, Wesierska-Gadek J, Kiliańska ZM. [New face of antiapoptotic proteins. I. Protein Mcl-1]. Postepy Biochem. 2007; 53(3): 228-238, indexed in Pubmed: 18399351.

43. Salas A, Ponnusamy S, Senkal CE, et al. Sphingosine kinase-1 and sphingosine 1-phosphate receptor 2 mediate Bcr-Abl1 stability and drug resistance by modulation of protein phosphatase 2A. Blood. 2011; 117(22): 5941-5952, doi: 10.1182/ /blood-2010-08-300772, indexed in Pubmed: 21527515.

44. Li QF, Wu CT, Duan HF, et al. Activation of sphingosine kinase mediates suppressive effect of interleukin-6 on human multiple myeloma cell apoptosis. Br J Haematol. 2007; 138(5): 632-639, doi: 10.1111/j.1365-2141.2007.06711.x, indexed in Pubmed: 17686057.

45. Tian H, Yu Z. Resveratrol induces apoptosis of leukemia cell line K562 by modulation of sphingosine kinase-1 pathway.
Int J Clin Exp Pathol. 2015; 8(3): 2755-2762, indexed in Pubmed: 26045781.

46. Li QF, Wu CT, Guo Q, et al. Sphingosine 1-phosphate induces Mcl-1 upregulation and protects multiple myeloma cells against apoptosis. Biochem Biophys Res Commun. 2008; 371(1): 159 -162, doi: 10.1016/j.bbrc.2008.04.037, indexed in Pubmed: 18423379.

47. García-Bernal D, Redondo-Muñoz J, Dios-Esponera A, et al. Sphingosine-1-phosphate activates chemokine-promoted myeloma cell adhesion and migration involving $\alpha 4 \beta 1$ integrin function. J Pathol. 2013; 229(1): 36-48, doi: 10.1002/path.4066, indexed in Pubmed: 22711564

48. Nishimura H, Akiyama T, Monobe Y, et al. Expression of sphingosine-1-phosphate receptor 1 in mantle cell lymphoma. Mod Pathol. 2010; 23(3): 439-449, doi: 10.1038/modpathol.2009.194, indexed in Pubmed: 20081804.

49. Bode C, Berlin M, Röstel F, et al. Evaluating sphingosine and its analogues as potential alternatives for aggressive lymphoma treatment. Cell Physiol Biochem. 2014; 34(5): 1686-1700, doi: 10.1159/000366370, indexed in Pubmed: 25401781.

50. Flori M, Schmid CA, Sumrall ET, et al. The hematopoietic oncoprotein FOXP1 promotes tumor cell survival in diffuse large B-cell lymphoma by repressing S1PR2 signaling. Blood. 2016; 127(11): 1438-1448, doi: 10.1182/blood-2015-08-662635, indexed in Pubmed: 26729899.

51. Koresawa R, Yamazaki K, Oka D, et al. Sphingosine-1-phosphate receptor 1 as a prognostic biomarker and therapeutic target for patients with primary testicular diffuse large B-cell lymphoma. Br J Haematol. 2016; 174(2): 264-274, doi: 10.1111/bjh.14054, indexed in Pubmed: 27061580.

52. Evangelisti C, Evangelisti C, Teti G, et al. Assessment of the effect of sphingosine kinase inhibitors on apoptosis, unfolded protein response and autophagy of T-cell acute lymphoblastic leukemia cells; indications for novel therapeutics. Oncotarget. 2014; 5(17): 7886-7901, doi: 10.18632/oncotarget.2318, indexed in Pubmed: 25226616.

53. Xu L, Zhang Y, Gao M, et al. Concurrent targeting Akt and sphingosine kinase 1 by A-674563 in acute myeloid leukemia cells. Biochem Biophys Res Commun. 2016; 472(4): 662-668, doi: 10.1016/j.bbrc.2016.02.094, indexed in Pubmed: 26920060.

54. Tan SF, Liu X, Fox TE, et al. Acid ceramidase is upregulated in AML and represents a novel therapeutic target. Oncotarget. 2016; 7(50): 83208-83222, doi: 10.18632/oncotarget.13079, indexed in Pubmed: 27825124

55. Beider K, Rosenberg E, Bitner H, et al. The sphingosine-1-phosphate modulator FTY720 targets multiple myeloma via the CXCR4/CXCL12 pathway. Clin Cancer Res. 2017; 23(7): 1733-1747, doi: 10.1158/10780432.CCR-15-2618, indexed in Pubmed: 27697999.

56. Chen L, Luo LF, Lu J, et al. FTY720 induces apoptosis of M2 subtype acute myeloid leukemia cells by targeting sphingolipid metabolism and increasing endogenous ceramide levels. PLoS One. 2014; 9(7): e103033, doi: 10.1371/journal.pone.0103033, indexed in Pubmed: 25050888.

57. Smith P, O’Sullivan C, Gergely P. Sphingosine 1-phosphate signaling and its pharmacological modulation in allogeneic hematopoietic stem cell transplantation. Int J Mol Sci. 2017; 18(10), doi: 10.3390/ijms18102027, indexed in Pubmed: 28934113.

58. Vrzalikova K, Ibrahim M, Vockerodt M, et al. S1PR1 drives a feedforward signalling loop to regulate BATF3 and the transcriptional programme of Hodgkin lymphoma cells. Leukemia. 2018; 32(1): 214-223, doi: 10.1038/leu.2017.275, indexed in Pubmed: 28878352 